\title{
Eksplorasi Limbah Kulit Nanas sebagai Biomaterial dalam Menanggulangi Permasalahan Korosi pada Baja
}

Ria Gracia Sibarani ${ }^{1}$, Putri Ramadhanti ${ }^{2}$, Gilang KurniawanSyah ${ }^{3}$, Diah Riski Gusti ${ }^{* *}$

${ }_{1,2,3,4}$ Program Studi Kimia Fakultas Sains dan Teknologi Universitas Jambi, Jambi, Indonesia

Email Penulis diahgusti@unja.ac.d

\section{Info Artikel}

Diterima: 29 November 2020

Disetujui: 18 Januari 2021

Dipublikasikan: 13 Maret 2021

\begin{abstract}
Abstrak
Baja merupakan material yang banyak digunakan dalam industri. Permasalahan yang sering terjadi pada baja yaitu korosi. Salah satu cara yang dapat digunakan untuk menghambat korosi yaitu dengan penggunaan inhibitor. Kerja inhibitor adalah menurunkan laju korosi pada baja. Pada penelitian ini memanfaatkan ekstrak kulit nanas sebagai inhibitor organik. Dilakukan perendaman baja pada dua medium korosi yaitu $\mathrm{H}_{2} \mathrm{SO}_{4} 0,75 \mathrm{M}$ dan $\mathrm{NaCl} 1 \mathrm{M}$ dan dilakukan variasi perendaman baja selam 2, 4, 6, 8 dan 10 hari. Ekstrak kulit nanas positif mengandung tanin dan alkaloid. Senyawa- senyawa metabolit sekunder tersebut memiliki gugus fungsi $\mathrm{O}, \mathrm{N}$ dan ikatan rangkap sehingga berpotensi sebagai biomaterial inhibitor korosi. Hasil penelitian menunjukkan bahwa laju korosi baja dalam medium korosi $\mathrm{H}_{2} \mathrm{SO}_{4}$ lebih besar dibandingkan $\mathrm{NaCl}$ pada perendaman selama 10 hari yaitu $0.37 \mathrm{mg} / \mathrm{cm}^{2}$ jam Untuk nilai efisiensi inhibisi yaitu nilai yang menunjukkan kemampuan ekstrak kulit nanas dalam menghambat korosi baja yaitu sebesar $57,7105 \%$ pada $\mathrm{H}_{2} \mathrm{SO}_{4} 0,75 \mathrm{M}$ dan $66,2498 \%$ pada $\mathrm{NaCl} 1 \mathrm{M}$
\end{abstract}

Kata kunci : Biomaterial; inhibitor organik; korosi dan kulit nanas

\section{Abstract :}

Steel is a material that is widely used in industry. A common mistake in steel is corrosion. One way that can be used to inhibit corrosion is using an inhibitor. The work barrier is to reduce the corrosion rate of the steel. In this study, using pineapple peel extract as an organic inhibitor. Steel immersion was carried out in two corrosion mediums, namely $0.75 \mathrm{M} \mathrm{H}_{2} \mathrm{SO}_{4}$ and $1 \mathrm{M} \mathrm{NaCl}$ and carried out variations of steel immersion for 2, 4, 6, 8 and 10 days. Pineapple peel extract positively contains tannins and alkaloids. These secondary metabolite compounds have functional groups $\mathrm{O}, \mathrm{N}$ and double bonds so that they only act as inhibitors of biomaterial corrosion. The results showed that the corrosion rate of steel in the corrosion of $\mathrm{H}_{2} \mathrm{SO}_{4}$ medium was greater than that of $\mathrm{NaCl}$, which was immersion for 10 days, namely $0.37 \mathrm{mg} / \mathrm{cm}^{2}$ jam For the value of inhibition efficiency, the value that showed the ability of pineapple peel extract to inhibit steel corrosion was $57.7105 \%$ in $\mathrm{H} 2 \mathrm{SO} 40,75 \mathrm{M}$ and $66,2498 \%$ in $1 \mathrm{M} \mathrm{NaCl}$

Keywords: Biomaterial;organic inhibitor; corrosion and pineapple peel 


\section{Pendahuluan}

Baja merupakan campuran besi dan karbon sebagai kandungan utama yang diantara logam sejenis paling banyak diaplikasikan dalam industri. Salah satu jenis baja yang paling banyak digunakan adalah baja lunak karena mudah diperoleh dan difabrikasi (Gusti dkk, 2015). Sebagai contoh, baja lunak digunakan sebagai pipa pabrik pengilangan minyak bumi. Akan tetapi kelemahan dari baja yaitu sangat mudah terkorosi. Korosi menyebabkan kerusakan pada peralatan dan kecelakaan yang terjadi pada proses industri sehingga membutuhkan biaya yang tinggi (Loto dan Olowoyo, 2018).

Oleh karena itu diperlukan suatu cara untuk menghambat terjadinya proses korosi. Salah satu cara yang dapat digunakan untuk menghambat laju korosi yaitu dengan penggunaan inhibitor. Penggunaan inhibitor korosi telah banyak dilaporkan dan sangat efisien untuk mengontrol proses korosi. Inhibitor korosi dapat berupa senyawa organik, anorganik, ataupun campurannya. Senyawa inhibitor anorganik yang dapat digunakan yaitu natrium kromat, fosfat, dan molibdat yang memiliki sifat toksik dan karsinogenik. Umumnya, senyawa organik yang efektif digunakan sebagai biomaterial inhibitor korosi adalah senyawa yang memiliki gugus fungsi elektronegatif seperti $\mathrm{S}, \mathrm{O}$, $\mathrm{P}$ atau $\mathrm{N}$ dan ikatan rangkap pada molekulnya yang dapat diadsorpsi pada permukaan logam (Gusti dkk, 2017, Emriadi dkk, 2016).

Yeragamreddy dkk (2013) telah melaporkan bahwa kulit nanas positif mengandung tanin, saponin, steroid, flavonoid, fenol dan alkaloid. Senyawa- senyawa metabolit sekunder tersebut memiliki gugus fungsi $\mathrm{O}, \mathrm{N}$ dan ikatan rangkap sehingga berpotensi sebagai biomaterial inhibitor korosi. Apalagi diketahui bahwa Jambi tepatnya desa Tangkit Baru merupakan daerah sentra produksi nanas. Menurut Tribun Jambi (2015), produksi buah nanas di Jambi setiap tahunnya menghasilkan sekitar 1.563 kuintal nanas. Kulit nanas merupakan limbah produk hasil olahan yang terdiri dari sisa daging buah. Jika kulit nanas tidak dimanfaatkan bisa menyebabkan pencemaran lingkungan. Oleh karena itu diperlukan penelitian mengenai eksplorasi limbah kulit nanas sebagai biomaterial dalam menanggulangi permasalahan korosi pada baja.

\section{Metode Penelitian}

Penelitian ini berupa jenis penelitian eksperimen dengan pendekatan kuantitatif. Bahan-bahan yang digunakan adalah kulit nanas, metanol (Merck), reagen uji fitokimia dan asam sulfat p.a (Merck). Alat-alat yang digunakan adalah alat-alat gelas, water bath, spektroskopi IR

\section{Prosedur Penelitian}

Pembuatan Ekstrak Metanol Kulit Nanas (Ananas comosus (L) Merr.)

Kulit nanas dipotong-potong sekecil mungkin lalu dijemur hingga kering selama \pm 7 hari. Kulit yang sudah kering kemudian dimaserasi dengan pelarut metanol selama 72 jam dalam botol berwarna gelap dan terhindar dari cahaya langsung. Kemudian dilakukan penyaringan antara residu dan filtrat sehingga diperoleh filtrat ekstrak metanol kulit nanas. Ekstrak yang diperoleh dipisahkan dari pelarutnya menggunakan water bath pada temperatur $\pm 50{ }^{\circ} \mathrm{C}$ hingga diperoleh ekstrak pekat. Ekstrak pekat kemudian dianalisa menggunakan instrumen FTIR dan dilakukan skrining fitokimia. Ekstrak pekat disimpan dalam gelas beker yang ditutup menggunakan aluminium foil sebelum digunakan.

Skrining Fitokimia Ekstrak Metanol Kulit Nanas (Ananas comosus (L) Merr.)

Skrining fitokimia mengacu pada Tiwari dkk (2011) yang meliputi uji alkaloid, fenolik, flavonoid, kuinon, saponin, steroid, tanin, dan terpenoid.

Uji alkaloid. $1 \mathrm{~mL}$ ekstrak dilarutkan dalam $2 \mathrm{~mL} \mathrm{HCl}$ encer kemudian disaring dan filtratnya dibagi ke dalam dua tabung reaksi. Filtrat a ditambahkan 3 tetes reagen Mayer (larutan merkuri dalam iodida). Terjadinya endapan putih mengindikasikan adanya senyawa alkaloid. Filtrat b ditambahkan 3 tetes reagen Dragendorff (larutan kalium bismut iodida). Terjadinya endapan merah bata mengindikasikan adanya senyawa alkaloid.

Uji fenolik. $1 \mathrm{~mL}$ ekstrak ditambahkan 3 tetes $\mathrm{FeCl}_{3} 1 \%$. Terbentuknya warna biru kehitaman mengindikasikan adanya senyawa fenolik.

Uji flavonoid. $1 \mathrm{~mL}$ ekstrak dilarutkan dalam $3 \mathrm{~mL}$ aquades lalu didihkan kemudian disaring. Filtrat ditambahkan $1 / 2$ sudip serbuk $\mathrm{Mg}, 1 \mathrm{~mL} \mathrm{HCl}$ pekat, dan $2 \mathrm{~mL}$ etanol. Dikocok kuat dan dibiarkan 
Volume 1 Nomor 1, Januari 2020

terpisah. Terbentuknya warna merah, kuning, atau jingga pada lapisan etanol menunjukkan adanya senyawa flavonoid

Uji kuinon. $1 \mathrm{~mL}$ ekstrak ditambahkan 3 tetes $\mathrm{NaOH} 1 \mathrm{M}$. Terbentuknya warna merah mengindikasikan adanya senyawa kuinon.

Uji saponin. $1 \mathrm{~mL}$ ekstrak dilarutkan dalam $2 \mathrm{~mL}$ aquades kemudian dikocok selama 1 menit dan biarkan terpisah. Terbentuknya lapisan busa mengindikasikan adanya senyawa saponin.

Uji terpenoid. $1 \mathrm{~mL}$ sampel ditambahkan dengan kloroform dan asetat anhidrat. Apabila terbentuk warna ungu atau jingga menandakan adanya triterpenoid.

Uji tanin. $1 \mathrm{ml}$ sampel ditambahkan $\mathrm{FeCl}_{3} 1 \%$ kemudian campuran dihomogenkan. Reaksi positif ditunjukkan dengan terbentuknya warna hitam kehijauan pada campuran.

\section{Pembuatan Larutan Medium Korosi $\mathrm{H}_{2} \mathrm{SO}_{4} 0,75 \mathrm{M}$}

Larutan $\mathrm{H}_{2} \mathrm{SO}_{4}$ pa $18 \mathrm{M}$ diencerkan menjadi $1 \mathrm{M} \mathrm{H}_{2} \mathrm{SO}_{4}$ kemudian diencerkan kembali menjadi 0,75 M.

\section{Pembuatan Larutan Medium Korosif NaCl 1 M}

Pembuatan larutan medium $\mathrm{NaCl} 1 \mathrm{M}$ yaitu dengan mencampurkan padatan $\mathrm{NaCl}$ ke dalam larutan aquades dengan jumlah tertentu. Lalu aduk larutan tersebut hingga bercampur rata.

\section{Pembuatan Larutan Inhibitor Korosi}

Larutan inhibitor ekstrak kulit buah nanas $5 \mathrm{~g} / 500 \mathrm{~mL}$ dibuat dengan cara melarutkan 5 gram ekstrak kulit buah nanas dengan larutan medium korosif dalam labu takar $500 \mathrm{ml}$ sampai tanda batas.

\section{Pembuatan Persiapan Spesimen Baja}

Baja lunak berukuran $\pm 2 \times 1 \mathrm{~cm}$ dilubangi menggunakan bor dengan diameter $3 \mathrm{~mm}$. Permukaan baja dihaluskan menggunakan amplas besi grade 120 lalu dicuci menggunakan aquades dan aseton. Kemudian didiamkan hingga kering selama \pm 5 menit. Diukur panjang dan lebarnya menggunakan jangka sorong lalu ditimbang massanya menggunakan neraca analitik dan hasilnya dinyatakan sebagai massa awal $\left(\mathrm{m}_{1}\right)$.

\section{Perendaman Baja Lunak Dalam Larutan Medium Korosif $\mathrm{H}_{2} \mathrm{SO}_{4}$ dan $\mathrm{NaCl}$ Tanpa Penambahan Larutan Inhibitor Korosi}

Baja lunak diikatkan dengan tali dan digantung pada tusuk gigi dalam gelas beker $50 \mathrm{~mL}$ yang berisi larutan medium korosif $\mathrm{H}_{2} \mathrm{SO}_{4}$ dengan konsentrasi $0,75 \mathrm{M}$ selama 2, 4, 6, 8 dan 10 hari. Baja yang sudah diangkat sesuai dengan waktu perendaman dicuci menggunakan aquades dan aseton. Kemudian diukur massanya menggunakan neraca analitik dan hasilnya dinyatakan sebagai berat akhir baja tanpa inhibitor $\left(\mathrm{W}_{2}\right)$.

Perendaman Baja dalam Larutan Medium Korosif $\mathrm{H}_{2} \mathrm{SO}_{4}$ dan $\mathrm{NaCl}$ Dengan Penambahan Larutan Inhibitor Korosi

Disediakan 5 buah gelas beaker $100 \mathrm{ml}$ pengujian yang telah diberi label kemudian diisi masingmasing wadah dengan medium korosif $\mathrm{H}_{2} \mathrm{SO}_{4}$ 0,75 M. Masing-masing wadah ditambah dengan larutan inhibitor sebanyak $50 \mathrm{ml}$ dengan konsentrasi $5 \mathrm{~g} / 500 \mathrm{~mL}$. Selanjutnya, baja lunak yang sudah disiapkan dimasukkan kedalam wadah masing-masing secara bersamaan dan setiap masing-masing sampel baja uji diambil pada hari ke 2, 4, 6, 8 dan 10 hari. Baja yang sudah diangkat sesuai dengan waktu perendaman dicuci menggunakan aquades dan aseton. Kemudian diukur massanya menggunakan neraca analitik dan hasilnya dinyatakan sebagai berat akhir baja dengan inhibitor $\left(\mathrm{W}_{3}\right)$. Prosedur yang sama juga dilakukan pada baja yang direndam pada larutan medium korosi $\mathrm{NaCl}$ dengan penambahan larutan inhibitor.

Data, Instrumen, dan Teknik Pengumpulan Data

\section{Karakterisasi FTIR (Fourier Transform Infra Red)}

Karakterisasi FTIR dilakukan dengan mengambil produk korosi (karat) yang menempel pada baja yang direndam selama 10 hari. Selain itu, karakterisasi FTIR juga dilakukan untuk ekstrak kulit nanas.

\section{Karakterisasi SEM (Scanning Electron Microcopy)}

Dilakukan karakterisasi Scanning Electron Microscopy (SEM) pada baja yang telah diamplas dan pada baja setelah perendaman selama 10 hari di dalam $\mathrm{H}_{2} \mathrm{SO}_{4}$ tanpa dan 
dengan adanya ekstrak kulit nanas serta baja yang direndam dalam $\mathrm{NaCl}$ tanpa dan dengan adanya ekstrak kulit nanas.

Teknik Analisis Data

\section{Penentuan Laju Korosi}

Laju korosi dan efisiensi inhibisi dihitung dengan persamaan 1 dan 2 (Irianty dan Khairat, 2013)

Laju korosi $(r)=\frac{W}{\text { A.t }}$

Keterangan :

$\mathrm{r}$ : Laju korosi ( gr/mm²hari)

W : Kehilangan berat (gram)

A : Luas permukaan $\left(\mathrm{mm}^{2}\right)$

$\mathrm{t}:$ Waktu (hari)

Penentuan Efisiensi Inhibisi

$\% \mathrm{E}=\frac{\mathrm{r} 1-\mathrm{r} 2}{\mathrm{r} 2} \times 100 \%$

Keterangan:

$\% \mathrm{E}$ : Efesiensi inhibisi (\%)

$\mathrm{r}_{1} \quad$ : Laju korosi tanpa inhibitor ( $\mathrm{gr} / \mathrm{mm}^{2}$ hari)

$\mathrm{r}_{2} \quad$ : Laju korosi dengan inhibitor $\left(\mathrm{gr} / \mathrm{mm}^{2} \mathrm{hari}\right)$

\section{Hasil Penelitian dan Pembahasan}

\section{Skrining Fitokimia Ekstrak Metanol Kulit Nanas (Ananas comosus (L) Merr.)}

Uji fitokimia merupakan uji yang dilakukan untuk mengetahui golongan senyawa metabolit sekunder apa yang terkandung dalam tumbuhan. Dari hasil uji fitokimia ekstrak kulit nanas menunjukkan hasil positif golongan alkaloid (pereaksi Meyer) dan tanin yang memiliki atom $\mathrm{O}, \mathrm{N}$ ikatan rangkap, dan pasangan elektron bebas (Gusti, dkk., 2015) Sedangkan untuk golongan flavonoid, kuinon dan saponin menunjukkan hasil negatif.

Tabel 1. Hasil analisis fitokimia ekstrak kulit nanas

\begin{tabular}{ccc}
\hline Pengujian Fitokimia & Pereaksi & Hasil \\
\hline Alkaloid & Meyer & + \\
Flavonoid & $\mathrm{Mg}, \mathrm{HCl}$ dan Etanol & - \\
Tannin & $\mathrm{FeCl} 31 \%$ & + \\
Saponin & Akuades & - \\
Kuinon & $\mathrm{NaOH} \mathrm{1} \mathrm{N}$ & - \\
\hline
\end{tabular}

\section{Karakterisasi FTIR (Fourier Transform Infra Red)}

FTIR digunakan untuk mengidentifikasi gugus fungsi dan senyawa yang terkandung dalam ekstrak air kulit nanas. Senyawa-senyawa metabolit sekunder yang memiliki gugus fungsi O, N, P dan S serta ikatan rangkap berpotensi sebagai biomaterial inhibitor korosi (Gusti, dkk., 2015). Hasil FTIR menunjukkan bahwa terjadinya pergeseran bilangan gelombang antara ekstrak air kulit kayu merkubung dan baja yang telah dilakukan perendaman selama 10 hari. 


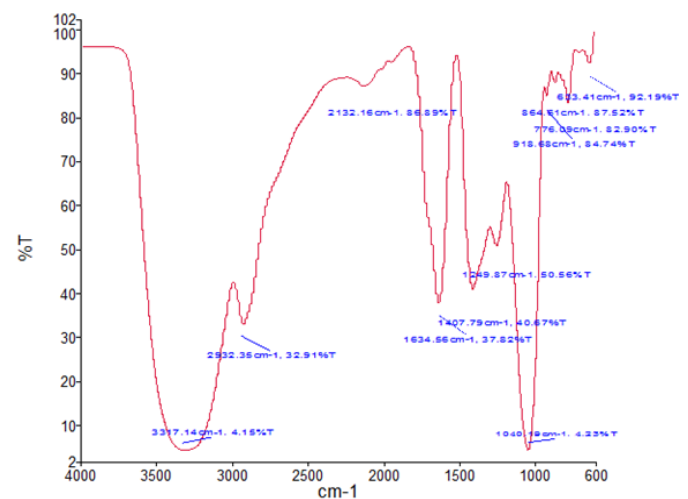

(a)

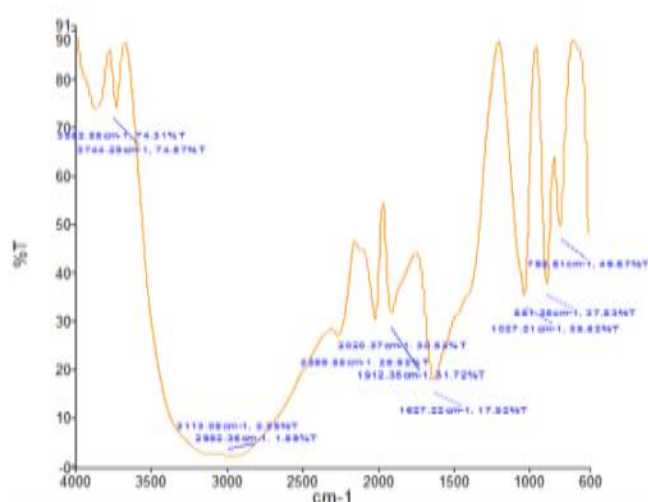

(b)

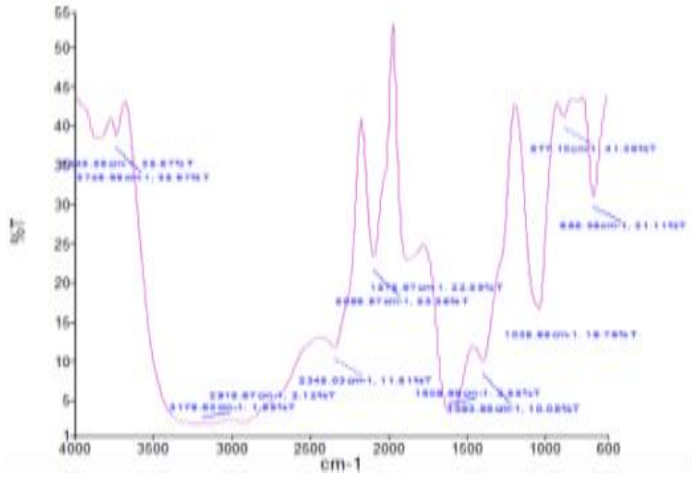

(c)

Gambar 1. (a) Ekstrak kulit nanas, lapisan permukaan baja setelah perendaman (b) $\mathrm{H}_{2} \mathrm{SO}_{4}+$ inhibitor (c) $\mathrm{NaCl}+$ inhibitor

Gambar 1 memperlihatkan pola yang berbeda dari ekstrak kulit nanas dibandingkan dari lapisan baja setelah perendaman dengan masing-masing media korosif. Hal ini menunjukkan telah terjadinya interaksi antara ekstrak kulit nanas dengan permukaan baja.

\section{Pengaruh waktu perendaman ekstrak kulit nanas terhadap efisensi inhibisi baja lunak}

Pengaruh waktu perendaman ekstrak kulit nanas terhadap efisiensi inhibisi baja lunak yaitu sebagai berikut:

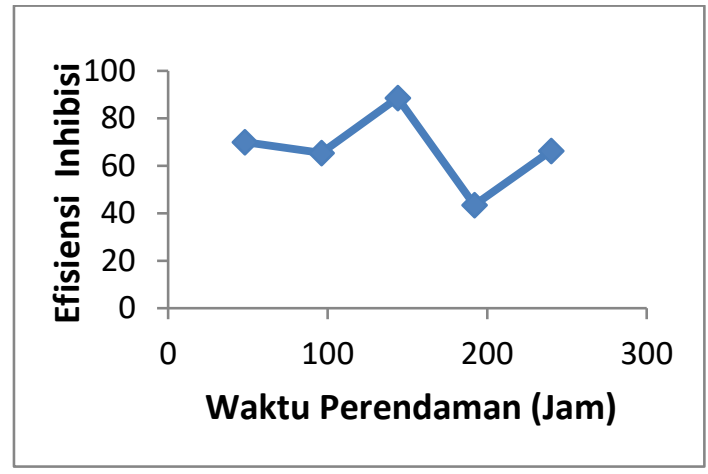

(a)

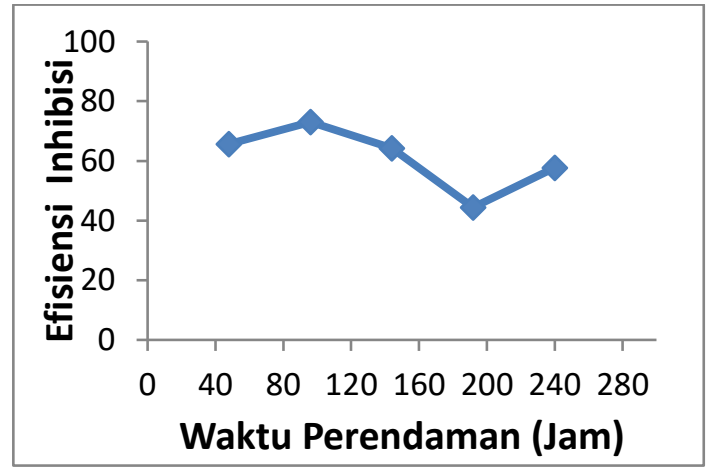

(b)

Gambar 2. Grafik hubungan efisiensi inhibisi dengan waktu perendaman (jam) (a). di dalam medium korosi $\mathrm{NaCl}$ (b). di dalam medium korosi $\mathrm{H}_{2} \mathrm{SO}_{4}$

Berdasarkan grafik diatas, pada gambar 2a dan $2 \mathrm{~b}$ grafik mengalami peningkatan dan penurunan hingga pada waktu perendaman $192 \mathrm{jam}$. Hal ini dikarenakan ekstrak kulit nanas belum melapisi permukaan baja secara keseluruhan sehingga efisiensi inhibisinya masih belum stabil. Sedangkan pada waktu perendaman 240 jam meningkat. Hal ini dikarenakan proses pengkaratan dan ekstrak yang melapisi semakin meluruh, sehingga efisiensi inhibisi yang diperoleh semakin tinggi. 
Pengaruh waktu perendaman ekstrak kulit nanas terhadap laju korosi baja lunak

Pengaruh waktu perendaman ekstrak kulit nanas terhadap laju korosi baja lunak yaitu sebagai berikut:

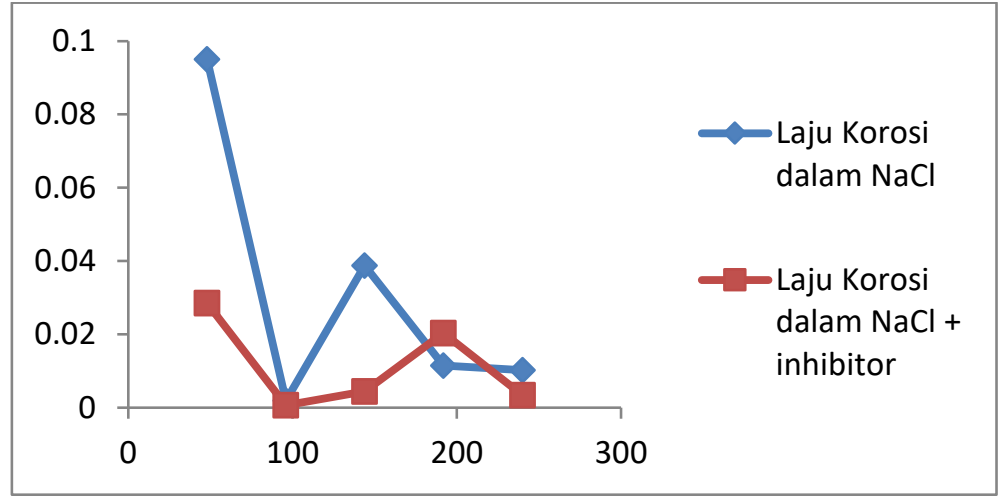

(a)

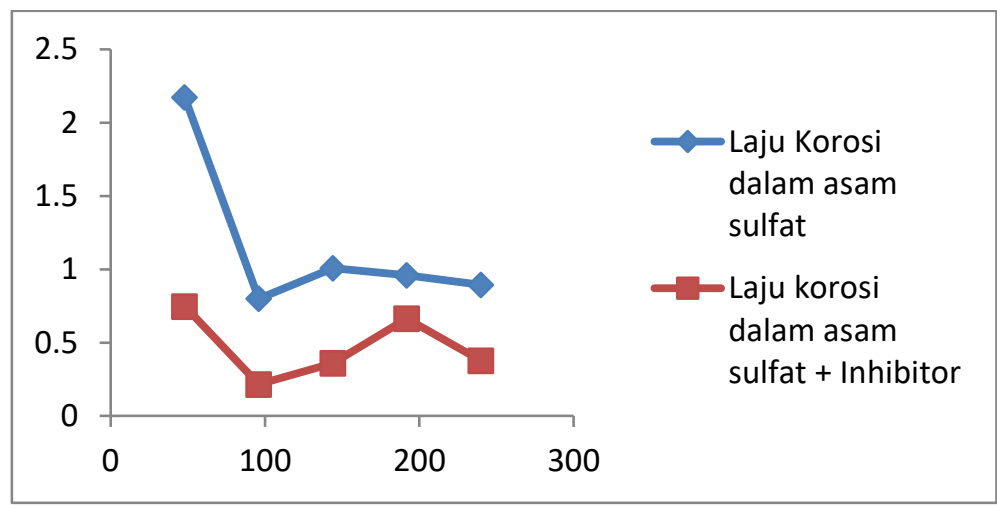

(b)

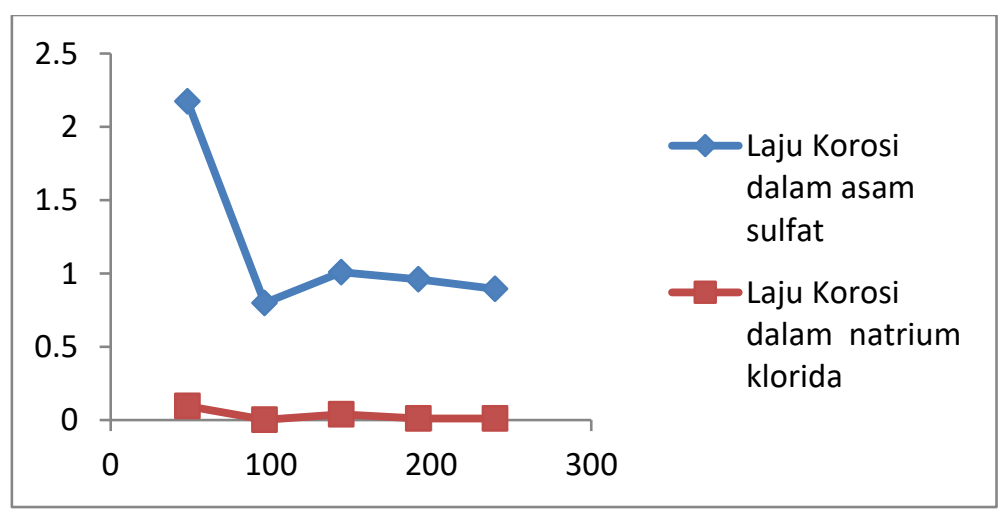

(c)

Gambar 3. Grafik hubungan laju korosi terhadap waktu perendaman (a). $\mathrm{NaCl}$ dan $\mathrm{NaCl}+$ inhibitor (b). $\mathrm{H}_{2} \mathrm{SO}_{4}$ dan $\mathrm{H}_{2} \mathrm{SO}_{4}+$ inhibitor (c). $\mathrm{H}_{2} \mathrm{SO}_{4}$ dan $\mathrm{NaCl}$

Pada gambar 3a menunjukkan grafik antara $\mathrm{NaCl}$ dengan $\mathrm{NaCl}+$ inhibitor. Pada saat setelah penambahan inhibitor menunjukkan bahwa ekstrak kulit nanas dapat menurunkan laju korosi pada baja. Gambar 3b menunjukkan grafik antara $\mathrm{H}_{2} \mathrm{SO}_{4}$ dengan $\mathrm{H}_{2} \mathrm{SO}_{4}+$ inhibitor, pada grafik $\mathrm{H}_{2} \mathrm{SO}_{4}$ laju korosi nya lebih besar daripada $\mathrm{H}_{2} \mathrm{SO}_{4}$ setelah penambahan inhibitor. Hal ini menunjukkan bahwa ekstrak kulit nanas berpotensi sebagai inhibitor korosi. Gambar 3c menunjukkan grafik antara $\mathrm{H}_{2} \mathrm{SO}_{4}$ dengan $\mathrm{NaCl}$. Pada grafik $\mathrm{H}_{2} \mathrm{SO}_{4}$ laju korosi nya lebih tinggi dibandingkan $\mathrm{NaCl}$. Hal ini 
dikarenakan $\mathrm{H}_{2} \mathrm{SO}_{4}$ bersifat lebih korosif daripada $\mathrm{NaCl}$. Pada dasarnya semakin lama waktu perendaman pada saat logam berinteraksi dengan lingkungan korosif maka semakin tinggi tingkat korosifitasnya. Adanya inhibitor diharapkan dapat membuat ketahanan logam terhadap korosi lebih besar. Dengan adanya penambahan inhibitor kedalam larutan, maka akan menyebabkan laju reaksi menjadi lebih rendah, sehingga waktu kerja inhibitor untuk melindungi logam menjadi lebih lama (Putra dan Kasuma, 2018).

\section{Karakterisasi SEM (Scanning Electron Microcopy)}

Hasil SEM yang diperoleh pada saat perendaman baja pada larutan medium korosi tanpa inhibitor dan menggunakan inhibitor mengalami perbedaan. Baja yang telah direndam dengan menggunakan larutan medium korosi tanpa inhibitor mengalami kerusakan dan pada permukaan baja rapuh sedangkan pada baja setelah direndam menggunakan larutan medium korosi dengan larutan inhibitor baja tetap kuat dan tidak rapuh.

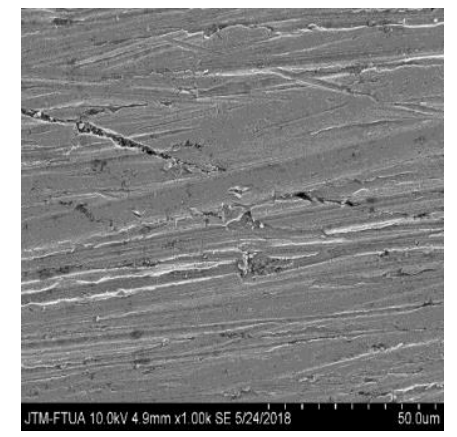

(a)

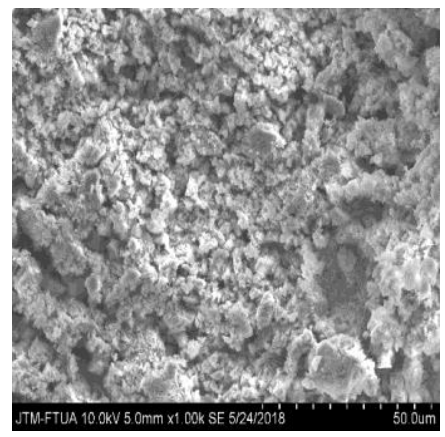

(b)

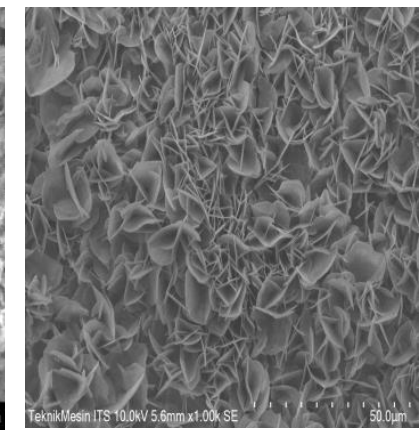

(c)

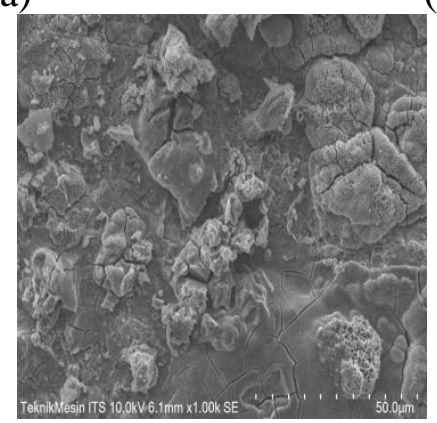

(d)

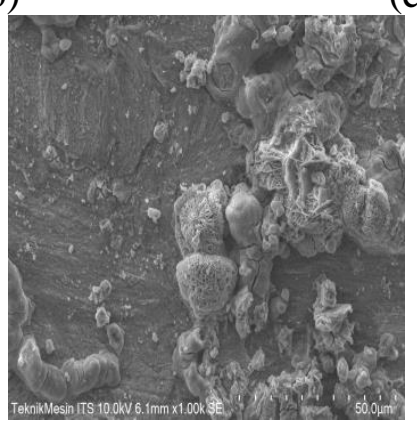

(e)

Gambar 4. (a) Baja setelah diamplas, (b) Baja direndam dengan medium korosi $\mathrm{H}_{2} \mathrm{SO}_{4}$, (c) Baja direndam dengan medium korosi $\mathrm{H}_{2} \mathrm{SO}_{4}$ ditambahkan inhibitor korosi, (d) Baja direndam dengan medium korosi $\mathrm{NaCl}$, (e) Baja direndam dengan medium korosi $\mathrm{NaCl}$ ditambahkan indikator korosi.

Berdasarkan gambar diatas, gambar 4a menunjukkan permukaan baja lunak yang masih bersih, halus, dan belum terdapat lubang-lubang akibat korosi. Garis-garis yang terlihat adalah akibat dari perlakuan preparasi (penghalusan) menggunakan amplas. Gambar 4b menunjukkan permukaan baja lunak yang kasar, tidak rata, dan terdapat lubang-lubang akibat korosi oleh asam sulfat. Gambar 4c menunjukkan permukaan baja lunak lebih halus dibandingkan Gambar 4a dan Gambar 4b. Gambar 4d menunjukkan permukaan baja lunak yang kasar, tidak rata, dan terdapat lubang-lubang akibat korosi oleh natrium klorida. Gambar 4e menunjukkan permukaan baja lunak lebih halus dibandingkan Gambar 4d. Hal ini dikarenakan terjadi karena senyawa metabolit sekunder yang terdapat dalam ekstrak metanol kulit nanas teradsorpsi pada permukaan baja lunak membentuk lapisan tipis dan melindunginya dari korosi (Gusti dkk., 2017).

\section{KESIMPULAN}

Dari analisis data yang diperoleh, nilai efisiensi inhibisi pada hari ke-10 pada larutan $\mathrm{H}_{2} \mathrm{SO}_{4}$ sebesar $57.7105 \%$ dan pada larutan $\mathrm{NaCl}$ sebesar $66.2498 \%$. Hal ini dikarenakan waktu yang sangat mempengaruhi perendaman pada baja sehingga semakin lamanya waktu maka ekstrak kulit nanas untuk menghambat korosi pada baja semakin baik. 


\section{Daftar Pustaka}

[1] Emriadi, Santoni A., Stiadi Y. 2016. Adsorptive and Thermodynamic Properties of Methanol Extract of Toona Sinensis Leaves for the Corrosion of Mild Steel in $\mathrm{HCl}$ Medium, Der Pharma Chemica, Vol 8, No 18, Page 266-273.

[2] Gusti D.R., Emriadi, Alif A., Efdi M. 2015. Water Extracts of Cassava Leaf as Corrosion Inhibitor for Mild Steel in Sulfuric Acid Solution, Journal of Chemical and Pharmaceutical Research, Vol 7, No 12, Page 398-405.

[3] Gusti, D.R., Emriadi, Alif A., Efdi M. 2017. Corrosion Inhibition of Ethanol Extract of Cassava (Manihot esculenta) Leaves on Mild Steel in Sulfuric Acid, International Journal of Chemtech Research, Vol 10, No 2, Page 163-171.

[4] Jones, D. (1992). Principles and prevention of corrosion. New York: Macmillan Publishing Company.

[5] Loto, R.T and Olowoyo O. 2018. Corrosion Inhibition Properties Of the Combined Admixture of Essential Oil Extracts on Mild Steel in the Presence of SO-2 Anions, South African Journal of Chemical Engineering. Vol 26, Page 35-41.

[6] Irianty, R. S dan Khairat. 2013. Ekstrak Daun Pepaya sebagai Inhibitor Korosi pada Baja AISI 4140 dalam Medium Air Laut, Jurnal Teknobiologi. Vol 4, No 2, Page 77-82.

[7] Nurdin, D. (2015). Ini Potensi Nanas di Desa Tangkit Baru Jambi. Diakses pada 26 Desember 2018 pukul 08.39 WIB. Diakses pada 26 Desember 2018 pukul 08.39 WIB dari http://jambi.tribunnews.com/2015/05/15/ini-potensi-nanas-di-desa-tangkit-barujambi.

[8] Putra, I. E dan Kasuma N.S. 2018. Pengaruh Inhibitor Daun Gambir Terhadap Laju Korosi Baja Karbon Rendahdalam Larutan HCl 1\%. Jurnal Momentum. Vol 20, No 1.

[9] Tiwari, P., Kumar B., Kaur M., Kaur G and Kaur H. 2011. Phytochemical Screening and Extraction: A Review, International pharmaceutica science, Vol 1, No 1, Page 98-106.

[10] Yatiman, P. (2009). Penggunaan inhibitor organik untuk pengendalian korosi logam dan paduan logam. Seminar Nasional Penelitian, Pendidikan dan Penerapan MIPA yang diselenggarakan oleh FMIPA UNY. Yogyakarta: Universitas Negeri Yogyakarta. 